\title{
From the Standpoint of Practical Reason
}

\section{A Reply to Tønder}

Rostbøll, Christian F.

Published in:

Political Theory

DOI:

DOI: $10.1177 / 0090591711400034$

Publication date:

2011

Document version

Early version, also known as pre-print

Citation for published version (APA):

Rostbøll, C. F. (2011). From the Standpoint of Practical Reason: A Reply to Tønder. Political Theory, 39(3), 386393. https://doi.org/DOI: 10.1177/0090591711400034 


\title{
Political Theory \\ http://ptx.sagepub.com/
}

\section{From the Standpoint of Practical Reason: A Reply to Tønder} Political Theory 2011 39: 386

DOI: $10.1177 / 0090591711400034$

The online version of this article can be found at:

http://ptx.sagepub.com/content/39/3/386

\author{
Published by: \\ (S) SAGE \\ http://www.sagepublications.com
}

Additional services and information for Political Theory can be found at:

Email Alerts: http://ptx.sagepub.com/cgi/alerts

Subscriptions: http://ptx.sagepub.com/subscriptions

Reprints: http://www.sagepub.com/journalsReprints.nav

Permissions: http://www.sagepub.com/journalsPermissions.nav

Citations: http://ptx.sagepub.com/content/39/3/386.refs.html 


\section{From the Standpoint of Practical Reason: A Reply to Tønder}

\section{Christian F. RostbølI'}

Lars Tønder's critical response to my article "Autonomy, Respect, and Arrogance in the Danish Cartoon Controversy" is mainly directed at my Kantian approach to autonomy, while he finds it "hard for any liberal or democratic pluralist to disagree" with my conclusions about respect for difference. ${ }^{2}$ In this reply I elaborate on what it means to view autonomy from the standpoint of practical reason and indicate how this can counter some of Tønder's objections.

To begin with, the aim of my article was not, as Tønder writes, to dissolve "the contradiction between free expression and respect for religious diversity" (p. 378), but the more fundamental one of exploring the possibility of reconciling a commitment to autonomy and respect for difference. The connection to freedom of expression is that this right is commonly justified with reference to autonomy, and my query was whether this justification is compatible with exercising freedom of expression in a way that shows respect for difference. I maintain that difference-sensitive respect is not only compatible with autonomy but presupposes it. We cannot without contradiction accept the duty of respect while rejecting the presupposition of autonomy, as Tønder does.

\section{Pluralization}

According to Tønder, we should not treat the twelve cartoons published by Jyllands-Posten as uniform in nature. He thinks such a reading contributes to seeing the conflict over the cartoons in binary terms and fails to foster the pluralization that he favors. It is certainly true that the twelve cartoons sent

\footnotetext{
'University of Copenhagen, Denmark

Corresponding Author:

Christian F. Rostbøll, University of Copenhagen, DK 1353, Copenhagen, Denmark

Email:cr@ifs.ku.dk
} 
very different messages; some of them even turned against Flemming Rose's commission to draw pictures of Muhammad.

There are two reasons why I did not discuss the diversity characterizing the cartoons. First, I take seriously the actual dividing lines in the Danish public sphere that were created or reinforced as a result of the publication of the cartoons, including how Muslims experienced the cartoons and the justification for their publication. Generally, neither those who criticized the publication of the cartoons nor those who defended it in Denmark stressed the plurality of messages of the cartoons. They mainly argued about the relative weight we should give to freedom of expression and respect for religious sentiments, respectively. Thus, I think that I take more seriously than does Tønder the actual life experiences and feelings of the involved parties.

Second, my concern in the article was the justification of freedom of expression and its relationship to how the right ought to be exercised. I focused on autonomy as a principle justifying freedom of expression, because many in the Danish debate referred to "the values of the Enlightenment" in their defense of the publication of the cartoons. It is correct that I did not consider the whole range of arguments given and in this sense my article does not do justice to "the pluralism inherent in the discussion" (379). The issue is not so much descriptive as whether disregarding the pluralism in the case may lead to a failure to exploit something normatively valuable inherent in the context.

It is not so clear that the alleged pluralism in the context supplies the normative resources we would need, and Tønder's own argument seems to run into problems. It assumes that all forms of pluralism are valuable and ignores that pluralization can be inegalitarian. Moreover, even if there were "pluralism" in the debate and among the cartoons this shows only disagreement and not the valuing of contestation and pluralization that Tønder needs for his purposes. While Tønder claims to be contextual and aiming at creating resonance with actual experiences, I don't find in the context the valuing of pluralism that his argument depends on. What I did find among Danish Muslims was a claim to be respected, and this claim was the immanent point of departure for my argument for Kantian autonomy. Claiming respect for one's way of life presupposes a commitment to autonomy, or so I argued.

\section{Kantian Autonomy and the Standpoint of Practical Reason}

At the core of Tønder's critical response stands his doubt that "a Kantian conception of autonomy can generate the conditions needed for a desirable combination of care and sensitivity" (378). The objection is that Kantian 
autonomy cannot motivate citizens to respect each other and thus foster pluralism. Thus Tønder collapses the question of whether, and if so how, we ought to treat others with respect - the question I aim to answer - and the question of what motivates and furthers such respect.

The issue of the relationship between morality and motivation is complex. Tønder seems to take for granted that if a norm does not motivate people, it does not apply to them. But it is not obvious that the fact that a moral principle does not motivate someone to act has any bearing on its validity. ${ }^{3}$ At least we need an argument as to why validity implies motivational appeal. Be that as it may, on the Kantian account we are committed to the idea that the moral law can be motivating. In Kant this raises the difficult question of how pure reason can be practical; something reason cannot explain without overstepping its boundaries. Even if reason cannot explain how pure reason can be practical, however, we cannot avoid presupposing that it is so and thus presupposing ourselves to be free and autonomous. ${ }^{4}$

In my article I didn't develop this Kantian idea but emphasized the difference between Kantian autonomy and Millian autonomy. The key difference between the two conceptions is not the content of autonomy but rather the standpoint from which we regard ourselves and others as autonomous. That we can regard ourselves from two different standpoints is a Kantian idea. ${ }^{5}$ On the Millian conception autonomy is a character ideal to strive for. This approach takes the standpoint from which human beings are regarded as phenomena, that is, as objects of knowledge and manipulation. Freedom of expression can be justified with reference to Millian autonomy as a means to promote people's actual autonomy. When autonomy is regarded from this standpoint, people can be described as more or less autonomous.

On the Kantian account, by contrast, autonomy is not something we sense or can explain human beings possess as objects of knowledge. Autonomy belongs rather to the standpoint of practical reason from which we ask what to do and how to treat ourselves and others. From this standpoint, we regard others "as active beings, as the authors of their thoughts and choices, as noumena." Autonomy is a quality we unavoidably presuppose everyone has, not because we can explain it but because it is required "for practical purposes ... to make use of our reason in our conduct." "7

Tønder thinks my commitments to Kantian autonomy and to context are incompatible. So let me clarify what I think it means for autonomy to belong to us as noumena rather than phenomena. Autonomy in this sense is not something that precedes our actions. Rather, Kantian autonomy is something that we presuppose in action, when we decide what to do, which choices to make, and which norms to submit to. The Kantian argument is that autonomy 
constitutes the very possibility of seeing ourselves as deliberating and moral agents. When we regard ourselves as deliberating and reason-responsive agents, we see ourselves as inhabiting a standpoint we share with others, because reasons are inherently shared. ${ }^{8}$ This approach does not disavow sensorial forces, it just rejects that they are the proper source of moral justification.

In the Danish cartoon case the most common demand raised by Muslims was to be treated with respect. The Kantian argument that I make in this connection is that equal respect for everyone's conception of the good presupposes regarding everyone as autonomous in the sense of being capable of judging for oneself which life plan to pursue. Kantian autonomy is something we cannot deny without undermining the possibility of seeing ourselves and others as moral beings worthy of equal respect. That everyone is owed equal respect requires the idea of Kantian autonomy, but in order to know whether someone is treated as an equal requires that we understand the context.

\section{The Egalitarianism of Kantian Autonomy}

The advantage of Kantian autonomy over Millian autonomy is the unqualified egalitarianism that lies in the idea of autonomy as something we presuppose and respect in every human being, as opposed to something variable that must be promoted in those lacking it. Tønder challenges me on this point and argues that Kant divides people "into two categories reflecting how well they fulfill their potential for being autonomous" (p. 380). Here we must distinguish between the question of whether one in Kant's writings can find such a division and the question of whether Kantian autonomy necessarily leads to such a division.

It is well known that one in Kant's writings can find examples of both sexism and racism, and in Kant's political writings we do not find the egalitarianism I claim. Tønder has, however, found an unfortunate example when he writes that Kant defends infanticide by the mother as a means for her to regain respectability (p. 381). First, the section from the Metaphysics of Morals that he refers to doesn't make an argument based on autonomy, and it is unclear which connection Tønder is implying. Second, the purpose of Kant's discussion of infanticide is not to justify it but rather to consider the difficulty of reconciling the demands of legal punishment with conventional morality based on honor. ${ }^{9}$

More important than Kant's prejudices is whether Kantian autonomy necessarily entails hierarchies of its own. If I understand Tønder correctly there are two parts to his argument: First, given disagreement over the meaning and 
value of autonomy, settling on one definition of autonomy privileges some groups over others. Second, Kantian autonomy implies certain obligations and those who fail to act accordingly must submit to the rule of the truly autonomous.

Regarding the first part of the argument, Tønder believes that when I speak of "morally permissible ends ... this leads right back to the Millian problem, because it assumes a set of values that people may or may not find acceptable" (p. 381). But this objection ignores the distinction Kantians draw between the right and the good. In relation to autonomy, this is the difference between regarding autonomy as the basis of a norm regulating social relations among people and seeing autonomy as referring to the content of the lives these people should live. Only the latter understanding of autonomy depends on that people value an autonomous life. Kantian autonomy does not depend on that people regard a life of critical self-reflection as the most valuable but only on that people treat each other as if they have chosen (or were able to choose and revise) their conception of the good self-reflectively. ${ }^{10}$

Still, Tønder might argue that as a principle regulating how we ought to relate to each other's autonomy also fails to be "truly universal; it is instead iterative, contestable, and always, even if paradoxically so, in difference with itself' (p. 380). I agree that the precise meaning of norms should be open to contestation and reinterpretation, but processes of contestation cannot be completely open and without normative guidelines. If we do not have any idea of what autonomy and respect mean and require, we lack a reason for holding that some processes of contestation (e.g., egalitarian or nonviolent ones) are better than others, and we lack the normative standard for regarding pluralization and inclusiveness in interpreting and giving binding norms as normatively valuable. ${ }^{11}$ The Kantian argument is that we do have some idea of what autonomy means and that it is presupposed in our common practices as deliberating, moral agents.

The second part of Tønder's argument for why Kantian autonomy necessarily leads to hierarchy relates to my conclusion that citizens ought to use their freedom of expression responsibly and with respect for others. He believes that those who fail to do so will not be treated as equals because they have failed to do what is required to be truly autonomous. But my argument for regarding autonomy from the standpoint of practical reason exactly excludes the possibility of comparing oneself with others as empirical beings who might fail to act according to duty. The point is that we owe respect to others as autonomous beings independently of what they do. Kant says, "Moral self-esteem, which is grounded in the worth of humanity, should not be derived from comparison with others, but from comparison with the moral law."12 
The preceding argument might not answer the objection that Kantian autonomy is insufficiently pluralistic because it "disavows . . . sensorial forces" (p. 381). I do not have the space to discuss why Kant thinks moral principles must be derived from a priori reasoning and how this relates to autonomy, but I must mention what I think is a misunderstanding. Tønder seems to assume that because moral principles cannot be derived from anything empirical in Kant, this also implies that there is no respect for actions affected by feelings and context. While Kant acknowledges that as phenomena human action is always affected by feelings and context, he does think we should respect human beings. He explicitly says that it is humanity that should be treated as an end, and humanity refers to our ability to set particular ends for ourselves. Such end-setting is not unaffected by context but it is nevertheless the ability that should be respected. ${ }^{13}$ The duty of equal respect cannot be derived from knowledge of human beings as empirical beings but requires the standpoint of practical reason where everyone is regarded as autonomous. Clearly more needs to be said to defend this idea, but let me instead note that while I can imagine that accentuating the sensorium can promote pluralization, I fail to see how it can ground respect for human equality. Tønder's appeal to Nietzsche might indicate that we can have pluralization without equality.

\section{Humility and Self-broadening}

In my article I argued that defenders of the cartoons failed to show the required humility and that they were often arrogantly ignoring Muslims' complaints. Tønder challenges my Kantian argument for humility, but it is unclear whether his claim is (1) that Kantian autonomy is not sufficiently humble and implies a form of arrogance or (2) that humility is the wrong obligation to promote. He cannot make the first criticism without invoking the wrongness of arrogance and the value of humility.

Humility might be thought to require arrogance because it depends on secure knowledge of what is the right norm to adhere to or on a specific understanding of what humility demands. While I agree that we should be open to discussing the precise meaning of humility and that failure to be so can be arrogant, it is self-defeating to reject the idea that there is some content to the concept. Tønder relies on this content when he attacks my use of Kantian autonomy for one-sidedness.

The objection that has some merit is that my article focused too much on a negative duty to limit oneself in the exercise of freedom of expression and ignored a more positive approach of self-broadening. If the invocation of 
humility gives the impression that I favor unworldly, disengaged citizens this should certainly be corrected. It is important to note that self-limitation is not sufficient for a more inclusionary public debate and that more proactive forms of expression might be needed. My point was that we ought not to express ourselves in ways that discourage others from participating as equals in public debate, and not that one should not encourage or even provoke participation and debate.

While there is a danger in emphasizing humility and the negative duty of self-limiting expression, we cannot discard it. We see this in Tønder's own approach. With his reference to the "admirable cartoonists who went against the intentions of Flemming Rose and Jyllands-Posten's editors," Tønder sets up an ideal of resilient public expression to be if not followed then esteemed. Hailing these cartoonists as "democracy's unsung heroes," Tønder establishes an aristocracy of good citizens, which seems to be unconstrained by the moral obligation to treat others as equals. It is exactly such an ideal of citizen virtue that I fear is implied by a Millian conception of autonomy, and which here only has attained a new formulation. Promoting such autonomy might be necessary and legitimate, but it must be constrained by the more fundamental Kantian conception of autonomy, which alone tells us why we should treat others as moral equals.

\section{Notes}

1. Political Theory 37, no 5 (October 2009): 623-48.

2. Lars Tønder, "Humility, Arrogance, and the Limitations of Kantian Autonomy: A Reply to Christian Rostbøll," Political Theory 39, 378. Subsequent references are given in the text.

3. Simon Caney, Justice Beyond Borders: A Global Political Theory (New York: Oxford University Press, 2005), 42.

4. Immanuel Kant, Groundwork of the Metaphysics of Morals, ed. Mary Gregor (Cambridge: Cambridge University Press, 1997), AK 4: 458-61.

5. Kant, Groundwork, AK 4: 452.

6. Christine M. Korsgaard, "Introduction," in Creating the Kingdom of Ends (Cambridge: Cambridge University Press, 1996), xi.

7. Kant, Groundwork, 4: 455-56.

8. Allen Wood, Kantian Ethics (New York: Cambridge University Press, 2008), 18f; Christine M. Korsgaard, The Sources of Normativity (Cambridge: Cambridge University Press, 1996), 131ff.

9. See Immanuel Kant, "The Metaphysics of Morals," in Practical Philosophy, trans. and ed. Mary Gregor (New York: Cambridge University Press, 1996), AK 6: 335-37. 
10. Cf. my "Kantian Autonomy and Political Liberalism," Social Theory and Practice (Forthcoming).

11. See further my "The Use and Abuse of 'Universal Values' in the Danish Cartoon Controversy,” European Political Science Review 2, no. 3 (2010): 401-422.

12. Kant, AK 27: 349, quoted by Allen Wood, "General Introduction," in Practical Philosophy, xviii.

13. For references and discussion, see Rostbøll, "Kantian Autonomy and Political Liberalism."

\section{About the Author}

Christian F. Rostbøll is an associate professor of political science at the University of Copenhagen, Denmark. He is the author of Deliberative Freedom: Deliberative Democracy as Critical Theory (2008), and of articles in, among other journals, Political Theory, Critical Review of International Social and Political Philosophy, Philosophy \& Social Criticism, European Journal of Political Theory, and European Political Science Review. 